\title{
Pengaruh Islam dan Budaya dalam Pembentukan Hukum di Indonesia
}

\author{
Ja'far Baehaqi \\ (Fakultas Syariah dan Hukum UIN Walisongo Semarang, Jl. Raya Walisongo No. \\ 35 Semarang, E-mail: baehaqi1@yahoo.co.id)
}

\begin{abstract}
Abstrak:
Terdapat hubungan antara Islam dan budaya di satu sisi dan hukum di sisi lain. Tulisan ini berusaha menjawab permasalahan tentang pengaruh Islam dan budaya dalam pembentukan hukum di Indonesia. Melalui pendekatan sistem diperoleh jawaban bahwa Islam dan budaya di Indonesia memainkan peran yang penting dalam menciptakan ketertiban dan kesalihan sosial. Sebagai suatu sistem kepercayaan komprehensif yang mencakup dimensi ukhrawî dan duniawi sekaligus Islam memainkan peran sebagai sumber inspirasi dan legitimasi. Sedangkan budaya sebagai produk manusia dalam merespon alam dan kehidupan yang dijalani memainkan peran sebagai pedoman hidup dan tingkah laku di samping agama. Sebagai sarana untuk menciptakan ketertiban maupun alat rekayasa sosial, hukum di Indonesia tidak bisa lepas dari Islam dan budaya. Pembentukan hukum negara niscaya harus mempertimbangkan Islam dan budaya. Kalau tidak, maka hukum akan terasing dan kehilangan relevansi.
\end{abstract}

\author{
Kata Kunci: \\ Pengaruh Islam, Budaya, Pembentukan Hukum, Indonesia
}

\begin{abstract}
:
There is a relationship between Islam and culture on the one hand and the law on the other hand. This paper attempts to answer the question about the influence of Islam and the culture in the formation of law in Indonesia. Through a system approach, it is found that Islam and culture in Indonesia plays an important role in creating social order and piety. As a comprehensive belief system that includes the dimensions of the hereafter and worldly life at the same time, Islam plays the role as a source of inspiration and legitimacy. Meanwhile, as a product of human in responding to natural and life lived, culture plays a role as a way of life and behavior in addition to the religion. As a means to create order and a tool of a social engineering, laws in Indonesia can not be separated from Islam and culture. Establishment
\end{abstract}

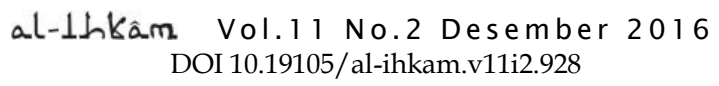


Ja'far Baehaqi

of state law will inevitably have to consider Islam and culture. Otherwise, the law will be alienated and lose its relevance.

\section{Key Words:}

The Influence of Islam, Culture, The Formation of Law, Indonesia

\section{Pendahuluan}

Bangsa Indonesia dikenal sebagai bangsa yang agamis, meskipun negaranya bukan negara agama. Suasana agamis tampak dalam keseharian melalui ritual ibadah dan perayaan hari besar keagamaan yang dilaksanakan oleh masyarakat, tempat-tempat ibadah yang ada di mana-mana, pemakaian idiom-idiom keagamaan dalam berbagai situasi dan kondisi, kontestasi bagian-bagian dari ritual keagamaan di dunia entertainment, maraknya bisnis-bisnis di sekitar ritual keagamaan, hingga kebijakan-kebijakan dan keterlibatan negara. Dengan demikian negara Indonesia merupakan negara dari sebuah bangsa yang beragama dan negara yang agamis.

Selain dikenal dari segi keberagamaannya, bangsa Indonesia juga merupakan bangsa dengan tingkat budaya yang tinggi. Dengan jumlah yang besar, terdiri dari berbagai macam suku, menempati wilayah yang luas dengan karakteristik yang berbeda, maka budaya yang dihasilkan bangsa Indonesia juga beraneka ragam. Budayabudaya itu berbentuk gagasan, tindakan maupun hasil karya dalam kehidupan masyarakat. Ketika kehidupan cenderung terstandarisasi akibat pengaruh global, karya-karya budaya itu mendapatkan pengakuan dengan nomenklatur kearifan lokal. Dengan demikian terdapat banyak sekali kearifan lokal yang di satu sisi diakui sebagai khazanah asli bangsa, manakala orang cenderung jenuh terhadap segala sesuatu yang semuanya serba sama dan standar serta hakikatnya mengandung unsur kolonialisme baru.

Dari beberapa agama yang diakui di Indonesia, Islam merupakan agama yang terbesar. Menurut Data Sensus Penduduk Tahun 2010 yang diterbitkan oleh Badan Pusat Statistik (BPS), penduduk Indonesia berjumlah 237.641.326 jiwa dan 207.176.162 jiwa di antaranya atau $87,18 \%$ adalah beragama Islam. ${ }^{1}$ Jumlah tersebut

1 Sebagai perbandingan, jumlah pemeluk agama lain adalah Kristen (6,96 \%), Katolik $(2,9 \%)$, Hindu (1,69 \%), Buddha (0,72 \%), Kong Hu Cu (0,05\%), agama lainnya $(0,13$

$\%)$, dan yang tidak terjawab atau tidak ditanyakan $(0,38 \%)$. "Penduduk Menurut 
merupakan yang terbesar di dunia diikuti oleh jumlah pemeluk Islam di India, yakni 174 juta jiwa. ${ }^{2}$ Dengan jumlah pemeluk yang besar tersebut, Islam di Indonesia mewarnai dan menentukan banyak aspek kehidupan berbangsa dan bernegara. Di antara aspek kehidupan bernegara yang diwarnai oleh Islam adalah hukum, baik sebagai suatu sistem ${ }^{3}$ yang berorientasi pada suatu tujuan tertentu maupun sebagai salah satu sub sistem masyarakat di antara beberapa subsubsistem yang lain yang kesemuanya berorientasi pada satu tujuan kolektif masyarakat.

Budaya sebagai sesuatu yang eksis dan berurat akar di tengah masyarakat juga berpengaruh terhadap hukum. Nilai penting budaya adalah keberadaannya yang menyatu dan menjadi bagian tak terpisahkan dari kehidupan bangsa Indonesia. Memang keragaman budaya menjadi persoalan manakala harus memilih personifikasi yang lebih sesuai dan relevan untuk bangsa Indonesia secara keseluruhan. Hal demikian terjadi ketika budaya berhadapan dengan hukum nasional yang cenderung uniform sebagai akibat kebijakan unifikasi.

Hukum di Indonesia sebagaimana hukum modern pada umumnya, yang dicirikan oleh bentuknya yang tertulis, berlaku untuk seluruh wilayah, dan berfungsi sebagai instrumen untuk mewujudkan keputusan-keputusan politik. ${ }^{4}$ Sistem hukum di Indonesia menjadikan negara sebagai raison d'etre dan menguasai satuan apa pun yang ada di dalamnya; kelompok etnis maupun wilayah geografis, dengan lembaga-lembaga negara sebagai pemegang posisi sentral baik dalam pembuatan maupun penerapannya. Dengan demikian pengaruh Islam sebagai agama dominan dan mayoritas dan budaya dengan berbagai ragamnya

Wilayah dan Agama yang Dianut" dalam http://sp2010.bps.go.id/index.php/si diakses tanggal 2 Juli 2016.

${ }^{2 " I n d i a ~ A k a n ~ K a l a h k a n ~ I n d o n e s i a ~ S o a l ~ P e m e l u k ~ I s l a m ” ~ d a l a m ~}$ https://m.tempo.co/read/new diakses tanggal 2 Juli 2016.

3 Sebagai suatu sistem hukum terdiri dari tiga sub sistem di dalamnya, yaitu substansi hukum, struktur hukum dan kultur hukum. Substansi hukum merupakan peraturan-peraturan tertulis, struktur hukum terkait aparatur hukum dan organisasinya, sedangkan budaya hukum terkait kepercayaan, nilai, pemikiran dan harapan. Lawrence M. Friedman, The Legal System, A Social Science Perspective, (New York: Russel Sage Foundation, 1975), 223.

4 Satjipto Rahardjo, Ilmu Hukum, Cet. V, (Bandung: PT. Citra Aditya Bakti, 2000), 214. 
terhadap hukum nasional, terutama dari segi pembuatannya, pada prosesnya juga bergantung pada politik hukum dan ketatanegaraan.

Asumsi dalam tulisan ini adalah bahwa Islam dan budaya sebagai sistem nilai, membentuk atau minimal mempengaruhi sikap, perilaku, harapan, dan cita-cita individu, kelompok maupun gabungan kelompok dalam lembaga politik. Sedangkan politik adalah determinan atas hukum oleh karena hukum merupakan produk politik. ${ }^{5}$ Di sini Islam dan budaya merupakan variabel bebas, sedangkan pembentukan hukum merupakan variabel terpengaruh. Di antara keduanya terdapat satu variabel, yaitu realitas politik sebagai variabel antara.

Dari paparan tersebut di atas, permasalahan yang dicari jawabannya dalam tulisan ini adalah bagaimana pengaruh Islam dan budaya dalam pembentukan hukum di Indonesia. Untuk membahas permasalahan tersebut digunakan pendekatan teori sistem yang digagas oleh Talcott Parsons sebagaimana dielaborasi lebih lanjut oleh Satjipto Rahardjo.

\section{Sub-sub Sistem Masyarakat ${ }^{6}$}

Masyarakat sebagai sebuah sistem yang terdiri dari subsubsistem budaya, sosial, politik, dan ekonomi dihadapkan pada dua kategori lingkungan yang otonom. Kedua lingkungan dimaksud adalah lingkungan transendental dan lingkungan fisik-organis. Kedua lingkungan ini berdiri sendiri dan memberikan bebannya terhadap masyarakat dan pada sub-subsistem yang membentuk masyarakat tersebut. Lingkungan transendental membebani masyarakat dengan informasi, sedangkan lingkungan fisik-organis membebani masyarakat dengan energi. Karena letaknya paling dekat dengan lingkungan transendental, subsistem budaya ${ }^{7}$ mengandung informasi

${ }^{5}$ Moh. Mahfud MD, Politik Hukum di Indonesia, Cet. II, (Jakarta: Pustaka LP3ES, 2001), 2,7 , dan 381 .

${ }^{6}$ Uraian dalam sub bahasan ini merujuk kepada elaborasi Satjipto Raharjo terhadap teori sistemnya Talcott Parsons dan hubungan sibernetiknya Harry C. Bredemeier. Satjipto Rahardjo, Ilmu Hukum..., 135-138; dan Satjipto Rahardjo, Membangun dan Merombak Hukum Indonesia Sebuah Pendekatan Lintas Disiplin, (Yogyakarta: Genta Publishing, 2009), 30-40.

7 Dalam perspektif ini agama dimasukkan dalam sub sistem budaya, oleh karena karakteristik ajaran-ajarannya yang mengarahkan dan memberikan pedoman. 
tertinggi yang dialirkan secara berurutan pada sub-subsistem sosial, politik, dan ekonomi.

Sebaliknya, karena berkaitan erat dengan lingkungan fisikorganis, subsistem ekonomi mengandung energi yang paling tinggi. Potensi energi ini kemudian dialirkan oleh subsistem ekonomi secara berurutan pada sub-subsistem politik, sosial, dan budaya. Dengan demikian, subsistem budaya adalah subsistem yang paling kaya informasi sekaligus paling miskin energi. Sebaliknya, subsistem ekonomi adalah subsistem paling kaya energi sekaligus juga paling miskin informasi. Kerangka yang mencakup hubungan saling terkait antara lingkungan transendental, masyarakat, dan lingkungan fisikorganis adalah sebagaimana bagan berikut.

\section{Hubungan Sibernetik}

(Sumber: Satjipto Rahardjo, 2009)

Kebenaran Sejati (Lingkungan Transendental)

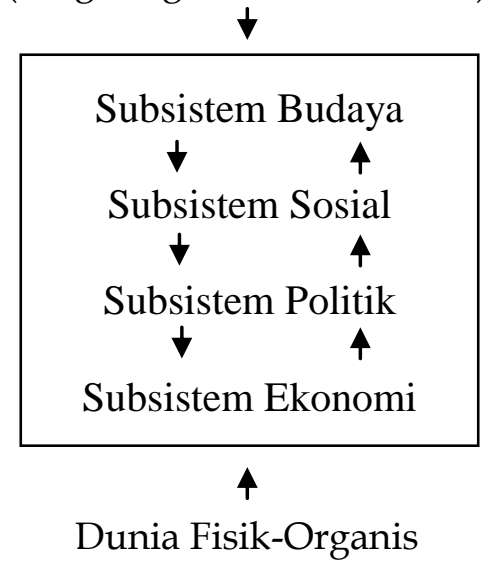

Setiap subsistem masyarakat mempunyai fungsi tersendiri, yang disebut fungsi primer. Subsistem budaya mempunyai fungsi mempertahankan pola; subsistem sosial mempunyai fungsi integrasi; subsistem politik mempunyai fungsi mencapai tujuan; dan subsistem ekonomi mempunyai fungsi adaptasi. 
Subsistem budaya yang mempunyai fungsi mempertahankan pola, menghubungkan lingkungan transendental (kebenaran sejati) dengan masyarakat. Subsistem ini menyerap lingkungan tersebut dengan membentuk nilai-nilai yang kemudian disebarkan ke dalam masyarakat. Dengan cara tersebut, subsistem budaya membentuk masyarakat menurut sistem nilai yang dipilihnya. Berfungsinya subsistem budaya membuat masyarakat mempunyai identitas sendiri yang diwarnai oleh pilihan nilai-nilainya.

Kehadiran nilai-nilai yang disebarkan oleh subsistem budaya tidak cukup mampu untuk mengatur interaksi sosial dalam masyarakat. Interaksi sosial mengarah kepada timbulnya konflik dan ketidakteraturan, sehingga menimbulkan masalah ketertiban. Subsistem sosial tampil mempertahankan asas-asas terakhir sekaligus secara aktif mendisiplinkan perilaku dan hubungan-hubungan dalam masyarakat dengan dukungan kekuatan sanksi. Di sini hukum mengkoordinasikan unit-unit dalam lalu lintas kehidupan sosial dengan memberikan pedoman orientasi tentang cara bertindak yang seharusnya.

Subsistem ekonomi menjadi penghubung antara masyarakat dengan lingkungan fisik-organis. Subsistem ekonomi memungkinkan masyarakat mempertahankan kelangsungan dan membentuk pola hidupnya. Mempertahankan kelangsungan hidup berarti kemampuan untuk menyerap dan memanfaatkan sumber-sumber daya yang terdapat dalam lingkungan bio-fisis tersebut. Fungsi adaptasi yang ada pada subsistem ekonomi mewujudkan diri dalam bentuk teknik-teknik pemanfaatan lingkungan dimaksud.

Sub-subsistem masyarakat itu dengan fungsinya masingmasing saling berhubungan satu sama lain dalam suasana yang dinamis yang disebut sibernetika. Tiap subsistem mempunyai tingkat independensi yang berbeda dan tidak absolut sifatnya.

Kerangka Parsons di atas dikembangkan lebih rinci oleh Harry C. Bredemeier. Ia menggambarkan bagaimana terjadinya proses hubungan antara sub-subsistem masyarakat dalam kerangka Parsons. Di sini subsistem sosial (hukum) bertindak sebagai katalisator masukan-masukan dari fungsi adaptasi (ekonomi), fungsi pengejaran tujuan (politik), dan fungsi mempertahankan pola (budaya) yang kemudian diolah hingga menghasilkan keluaran dalam bentuk penataan kembali proses produktif dalam masyarakat, legalisasi, dan 
implementasi tujuan-tujuan masyarakat, dan keadilan. ${ }^{8}$ Pola hubungan antarsubsistem itu digambarkan oleh Satjipto Rahardjo dalam bentuk bagan sebagai berikut.

Pola Pertukaran Antar Sub-sub Sistem Sosial

(Sumber: diadaptasi dari Satjipto Rahardjo, 2000)

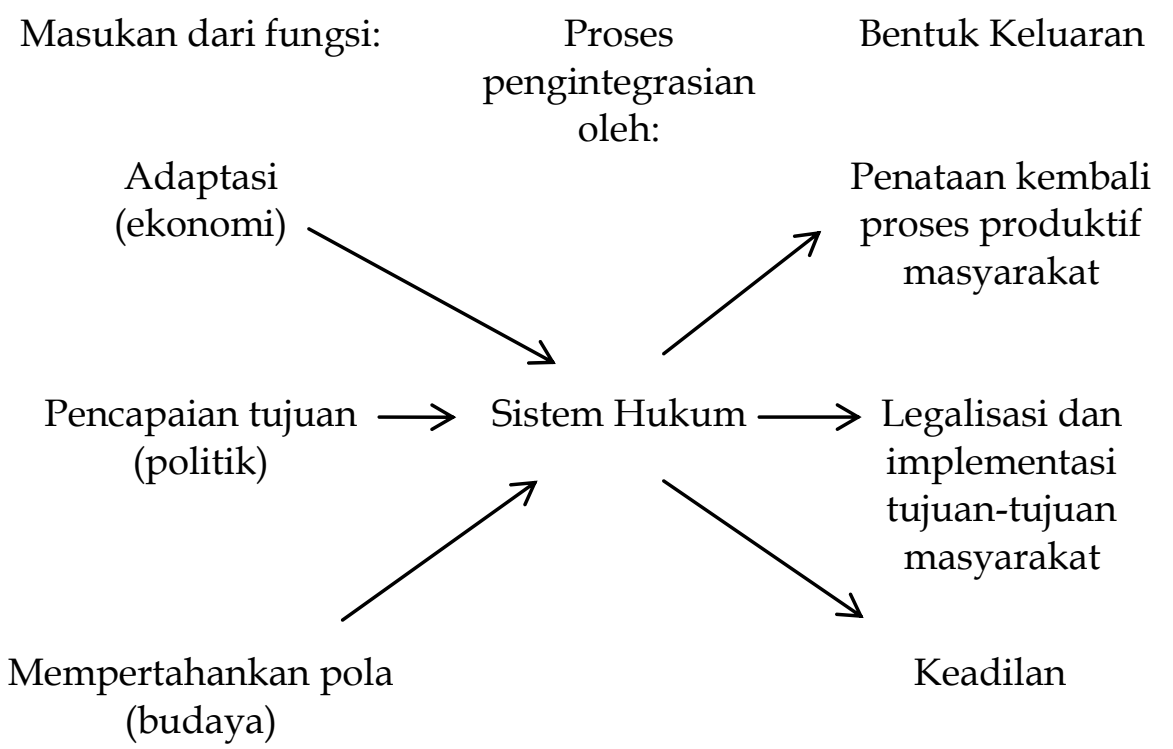

Dengan teori sibernetik dan pertukaran ini dikemukakan bahwa hukum bukan suatu fenomena yang jatuh secara tiba-tiba dari langit. Hukum merupakan bagian dari proses sosial yang berjalan dalam masyarakat. Oleh karena itu hukum tidak dapat dilepaskan dari konteks sosialnya, yaitu sub-subsistem politik, budaya dan ekonomi. ${ }^{9}$

Islam sebagai Sistem Kepercayaan: Sumber Inspirasi dan Legitimasi

Istilah Islam mengacu pada keseluruhan ajaran yang dibawa oleh Rasulullah Muhammad berdasarkan wahyu Allah. Dalam konteks ini istilah Islam sepadan dengan istilah syari'at dan dîn yang

8 Ibid., 137.

${ }^{9}$ Satjipto Rahardjo, Ibid., 140-142. 
berarti agama. Islam merupakan agama samawî (wahyu) terakhir, di samping Yahudi dan Nasrani yang datang lebih dahulu. Ketiga agama tersebut dibawa oleh keturunan Nabi Ibrahim, sehingga ia disebut sebagai ab al-adyân (bapak agama-agama).

Sistem dan bangunan Islam terdiri dari tiga pilar yaitu (1) subsistem aqîdah/keyakinan yang berkaitan dengan keberadaan Allah dan sifat-sifatnya, malaikat, para nabi dan rasul serta sifat-sifatnya, kitab suci yang telah diturunkan oleh Allah, hari akhir/kiamat dan taqdîr (ketentuan Allah yang berlaku pada makhluk-Nya); (2) subsistem mu'âmalah (bertindak/melakukan hubungan/perilaku lahir), baik terkait dengan Allah (ibâdah mahdlah/ibadah) maupun dengan selain Allah terutama sesama manusia (ibâdah ghayr mahdlah/mu'âmalah); dan (3) subsistem akhlak (perilaku batin) yang terkait dengan upaya menempa dan mengolah hati dalam berhubungan dengan-Nya. Bila subsistem aqîdah menjadi bidang kajian ilmu kalam, dan subsistem akhlak menjadi bidang kajian ilmu tasawuf, maka subsistem mu'âmalah menjadi bidang kajian figh/hukum Islam. ${ }^{10}$

Meskipun Islam ini mengandung ajaran yang komprehensif dengan tiga dimensinya sebagaimana dikemukakan di atas, namun dalam kehidupan keseharian tidak kesemuanya populer dan familiar bagi setiap muslim. Dari ketiga pilar tersebut pilar kedualah yang mendominasi. Dominasi ini nampak dari sebutan fiqh yang dipadankan dengan hukum Islam seolah-olah ajaran-ajaran Islam hanya yang berkaitan dengan pilar kedua. Sebutan ini sesungguhnya telah mereduksi kesempurnaan ajaran Islam, namun pada sisi yang lain ia menggambarkan betapa fiqh telah menjadi trademark hukum

\footnotetext{
10 Istilah mu'amâlah dalam Islam dipakai dalam tiga tingkatan. Pertama, menunjuk pada subsistem agama Islam yang berkaitan dengan tindakan/perbuatan nyata (alahkâm al-syar'iyyah al-'amaliyyah). Kedua, menunjuk pada suatu bagian dari sub sistem tindakan/perbuatan nyata yang objeknya adalah tindakan/perbuatan seseorang terhadap dirinya maupun orang lain. Ketiga, menunjuk pada suatu bagian dari tingkatan kedua di atas yang hanya berkaitan dengan kebendaan dan hak-hak serta penyelesaian sengketa-sengketa yang timbul. Bila istilah $m u^{\prime}$ âmalah disebut secara mutlak (tanpa embel-embel), maka yang dimaksud adalah tingkatan yang ketiga ini. Istilah fiqh muamalah pun merujuk pada tingkatan atau makna yang ketiga ini. Ja'far Baehaqi, "Dialektika Hukum Islam dan Hukum Nasional dalam formulasi Hukum Perbankan Syariah di Indonesia", Disertasi tidak diterbitkan, Program Doktor Ilmu Hukum Fakultas Hukum Universitas Diponegoro Semarang, 2013, 2.
} 
Islam oleh karena fiqh menyangkut perbuatan-perbuatan nyata dan praktis yang berlaku sehari-hari.11

Identifikasi fiqh sebagai hukum Islam diikuti pula oleh para aktifis Islam selama ini ketika memperjuangkan fiqh berhadapan dengan hukum negara. Bermula terkait kewenangan pengadilan agama di bidang perkawinan, kewarisan, wasiat, dan hibah berdasarkan fiqh pada masa kolonial, maka hingga beberapa lamanya perjuangan untuk mengakomodir "hukum Islam" dalam hukum nasional hanya sebatas pada materi fiqh, yaitu ibadah, munâkahah, mu'âmalah, dan jinâyah. Materi fiqh sebagaimana tergambar dalam empat bidang tersebut luas, namun seperti telah dikemukakan dalam paragraf di atas, bidang-bidang di luar materi fiqh masih luas pula.

Sebagai sebuah agama, Islam menuntut kepada pemeluknya untuk melaksanakan perintah-perintah Allah dan meninggalkan larangan-larangan-Nya sebagaimana terdapat dalam al-Qur'an dan Sunnah, baik secara langsung maupun tidak langsung. ${ }^{12}$ Pemeluk Islam yang taat disebut sebagai al-muttaqi (orang yang bertakwa) yang merupakan dambaan setiap muslim dalam hubungan dengan/terhadap Tuhannya, meskipun berat dan sulit mendapatkan nya. Bahkan perintah itu tidak bersifat individu dalam arti untuk seorang muslim secara pribadi, melainkan diperluas dengan adanya kewajiban/perintah untuk mengajak dan menyampaikannya kepada orang lain (da'wah/ tablikgh).

H.A.R. Gibb dalam bukunya The Modern Trends of Islam, seperti dikutip H. Ichtijanto, ${ }^{13}$ mengintroduksi sebuah teori yang dikenal

11 Ali Yafie, Menggagas Fiqih Sosial, Cet. 2, (Bandung: Mizan, 1994), 113-114; dan Muhaimin, “Dari Numerologi hingga Fiqih Sosial: Menyambut 70 Tahun Prof. K.H. Ali Yafie", dalam Jamal D. Rahman (et al.), Wacana Baru Fiqih Sosial, 70 Tahun Prof. K.H. Ali Yafie, Cet. 1, (Bandung: Mizan, 1997), 82.

12 Dikatakan bersumber dari al-Qur'an dan Sunnah secara langsung manakala norma perintah atau larangan itu terdapat di dalam keduanya atau salah satunya. Sedangkan jika norma dimaksud tidak diperoleh dalam kedua sumber tersebut, melainkan melalui analogi terhadap norma yang terdapat dalam kedua sumber tersebut atau salah satu darinya atau melalui metode-metode yang lain seperti istihsân, istishlâh, istishhâb, syar' man qablana, dan saddudz dzarî'ah, maka dikatakan bersumber secara tidak langsung.

${ }^{13}$ H. Ichtijanto S.A., "Pengembangan Teori Berlakunya Hukum Islam di Indonesia," dalam Cik Hasan Bisri, Hukum Islam di Indonesia: Pengembangan dan Pembentukan, (Bandung: PT. Rosda Karya, 1991), 114. 
sebagai teori penerimaan otoritas hukum Islam. Lewat teori ini, Gibb menyatakan bahwa jika seseorang telah menerima Islam sebagai agamanya, maka ia akan menerima otoritas hukum Islam terhadap dirinya.

Teori penerimaan otoritas hukum Islam itu dalam perspektif yang lain dikenal dengan teori kredo atau teori syahadat yang menyatakan bahwa orang yang telah mengucapkan dua kalimah syahadat diharuskan melaksanakan hukum Islam sebagai konsekuensi logis dari pengucapan kredonya. Teori kredo merupakan kelanjutan dari prinsip tauhid dalam filsafat hukum Islam. Prinsip tauhid menghendaki setiap orang yang menyatakan beriman kepada Allah harus tunduk kepada apa yang diperintahkan Allah. Dalam hal ini adalah taat kepada perintah Allah dalam al-Qur'an dan sekaligus pula taat kepada Muhammad selaku Rasul-Nya. ${ }^{14}$

Berdasarkan teori kredo/teori syahâdah tersebut maka setiap muslim berusaha untuk melakukan hal-hal yang sesuai dengan ajaran agamanya dalam setiap gerak langkahnya, baik di rumah, di tempat kerja, maupun di ruang-ruang publik di mana dia berada. Memang kualitas ketaatan seorang muslim terhadap ajaran agamanya tidak sama antara orang yang satu dengan yang lain. Ketaatan itu dipengaruhi oleh banyak hal, antara lain pengetahuan, penghayatan, dan situasi-kondisi yang melingkupinya.

Hal-hal yang berpengaruh terhadap ketaatan seorang muslim terhadap ajaran Islam dapat dibedakan menjadi dua, yaitu faktor internal dan faktor eksternal. Faktor internal menjadi urusan pribadi seorang muslim dengan tuhannya dengan atau tanpa partisipasi serta intervensi tokoh agama (ustadz, kyai, ulama). Sedangkan faktor eksternal menjadi domain negara melalui kebijakan-kebijakan yang dikeluarkan, baik yang diformulasikan dalam produk perundangundangan maupun tidak. Di sini bisa diteorisasikan dengan meminjam istilah dalam ilmu ekonomi makro,15 bahwa jika faktor

\footnotetext{
14 Juhaya S. Praja, "Aspek Sosiologi dalam Pembaharuan Fiqh di Indonesia," dalam Anang Haris Himawan (peny.), Epistemologi Syara', Mencari Format Baru Figh Indonesia, (Yogyakarta: Walisongo Press bekerjasama dengan Pustaka Pelajar, 2000), 125-126.

15 Istilah ceteris paribus berasal dari bahasa Latin yang artinya semua hal yang lain tetap. Konsep itu dipakai ketika hendak mengetahui perbedaan pengaruh terhadap sesuatu yang ditimbulkan oleh dua variabel atau lebih dan dimaksudkan untuk
} 
eksternal kondusif, ceteris paribus (semua hal-hal yang bersifat internal tetap), maka ketaatan umat Islam pada ajaran Islam juga akan naik. Teori ini mempunyai relevansi dengan setting sosial masa lalu ketika umat Islam tidak dapat menjalankan ajaran Islam dan dipaksa menurut ketentuan yang ditetapkan oleh negara.

Dalam konteks keterlibatan negara sesungguhnya pelaksanaan ajaran Islam ditentukan oleh tipe-tipe ajaran-ajaran Islam itu sendiri sebagai berikut. Pertama, ajaran Islam yang pelaksanaannya serba bersifat mandiri dan sekali-kali tidak memerlukan keterlibatan negara. Di sini negara hanya perlu menjamin setiap muslim dapat menjalankannya tanpa ada gangguan atau halangan dari siapa pun. Kedua, ajaran Islam yang pada dasarnya dapat dilaksanakan secara mandiri oleh umat Islam, namun keterlibatan negara dapat menjamin dan meningkatkan kualitas pelaksanaannya. Ketiga, ajaran Islam yang tidak mungkin dilaksanakan tanpa keterlibatan fasilitas negara.

Ketiga tipe ajaran Islam tersebut secara keseluruhan sesungguhnya memerlukan keterlibatan negara, baik dengan mengeluarkan kebijakan yang menjamin pelaksanaannya maupun dengan tidak membuat kebijakan yang bertentangan dengan ajaranajaran dimaksud. Dalam konteks negara hukum kebijakan tersebut dituangkan dalam peraturan, baik termasuk kategori peraturan perundang-undangan sebagaimana diatur dalam UU Nomor 12 Tahun 2011 tentang Pembentukan Peraturan Perundang-undangan atau bukan, yang menjamin, mempermudah, dan memungkinkan pelaksanaan ajaran Islam. Sebaliknya, jika negara mengeluarkan peraturan yang bertentangan atau menghambat pelaksanaan ajaran Islam, maka peraturan tersebut kehilangan legitimasi di mata umat Islam.

\section{Budaya sebagai Pedoman Tingkah Laku}

Dalam perspektif teori sistem Talcot Parsons, sistem budaya sebagai sub sistem dalam masyarakat mempunyai fungsi mempertahankan pola, karena kedekatannya dengan lingkungan

mengetahui besaran pengaruh masing-masing. Jika menghendaki perubahan satu variabel saja, sedangkan variabel yang lain tetap, maka hal itu harus dinyatakan. Pada umumnya untuk maksud itu dipakai istilah ceteris paribus. Suherman Rosyidi, Pengantar Teori Ekonomi Pendekatan kepada Teori Ekonomi Mikro dan Makro, Edisi Baru (Jakarta: PT RajaGrafindo Persada, 2004), 247. 
transendental. Sistem budaya juga berpengaruh terhadap hukum sebagai sub sistem sosial.

Koentjaraningrat mendefinisikan kebudayaan sebagai keseluruhan sistem gagasan, tindakan, dan hasil karya manusia dalam kehidupan masyarakat yang didapat dengan belajar. ${ }^{16}$ Ruth Benedict, sebagaimana dikutip oleh Daeng, 17 mengatakan bahwa kebudayaan merupakan pola-pola pemikiran serta tindakan tertentu yang terungkap dalam aktivitas dan pada hakikatnya merupakan way of life, cara hidup tertentu yang memancarkan identitas tertentu pada suatu bangsa. Sedangkan King dan Umar Kayam ${ }^{18}$ memberikan definisi kebudayaan sebagai upaya masyarakat untuk terus menerus secara dialektis menjawab setiap tantangan yang dihadapkan kepadanya dengan menciptakan berbagai prasarana dan sarana. Dengan kata lain, kebudayaan adalah proses terus-menerus menyimak kadar dinamika dari sistem nilai dan sistem kepercayaan yang mapan dalam masyarakat.

Tiap kebudayaan pada umumnya mempunyai sedikitnya tiga wujud, ${ }^{19}$ yaitu suatu himpunan gagasan, sejumlah perilaku yang berpola serta sekumpulan benda dan artifacts. Gagasan merupakan wujud kebudayaan yang paling abstrak. Dalam wujud ini kebudayaan tidak dapat dilihat atau diamati, karena tersimpan dalam kepala orang yang membawanya kemana pun pergi. Kebudayaan dalam wujud himpunan gagasan ini disebut sistem budaya (cultural system). Dalam wujudnya yang kedua kebudayaan disebut sistem sosial (social system), sedangkan dalam wujudnya yang ketiga disebut kebudayaan fisik (physical culture).

Sistem nilai budaya merupakan bagian dari sistem budaya, yaitu aspek dari sistem gagasan. Sistem nilai budaya adalah sejumlah pandangan mengenai soal-soal paling berharga dan bernilai dalam

\footnotetext{
16 Koentjaraningrat, Pengantar Antropologi (Jakarta: Rineka Cipta, 1991), sebagaimana dikutip Eko A. Meinarno, dkk., Manusia dalam Kebudayaan dan Masyarakat Pandangan Antropologi dan Sosiologi, Edisi II, (Jakarta: Salemba Humanika, 2011), 90.

17 Hans J. Daeng, Manusia, Kebudayaan dan Lingkungan Tinjauan Antropologis, (Yogyakarta: Pustaka Pelajar, 2000), 45.

18 Nat J. Colletta King dan Umar Kayam, Kebuadayaan dan Pembangunan Sebuah Pendekatan terhadap Antropologi Terapan di Indonesia (Jakarta: Yayasan Obor Indonesia, 1987), 313.

19 Hans J. Daeng, ibid., 46.
} 
hidup. Sebagai inti dari suatu sistem kebudayaan, sistem nilai budaya menjiwai semua pedoman yang mengatur tingkah laku warga pendukung kebudayaan yang bersangkutan. Pedoman tingkah laku itu adalah adat istiadat, sistem norma, aturan etika, aturan moral, aturan sopan santun, pandangan hidup dan ideologi pribadi.

Dengan demikian, sistem nilai budaya bisa identik dengan atau setidaknya mengandung esensi ajaran agama dan bisa pula berbeda dan tidak mengandung esensi ajaran agama tertentu. Kecuali itu, banyak sistem budaya yang di dalamnya mengandung beberapa sistem nilai budaya yang berasal dari beberapa esensi ajaran berbagai agama karena digagas dan berkembang di tangan pemeluk agama yang berbeda.

Di Indonesia di kalangan umat Islam pun berkembang sistem nilai budaya yang bermacam-macam. Sebagian dari sistem nilai budaya itu mengandung esensi ajaran Islam, sebagian yang lain mengandung pula esensi ajaran agama/kepercayaan di luar Islam, dan sebagian yang lain lagi sama sekali tidak mengandung esensi ajaran Islam. Yang demikian itu dimaklumi oleh karena eksistensi sistem-sistem nilai budaya tersebut terdapat pada praktik-praktik budaya yang telah ada sebelum atau berasal dari luar Islam. Terhadap praktik-praktik tersebut Islam mengelaborasi esensi-esensi ajarannya ke dalamnya secara halus dan perlahan. Atau praktik-praktik itu tidak disentuh oleh Islam oleh karena sejak awal keberadaannya tidak dibenarkan atau dianggap tidak mempunyai relevansi untuk penyiaran Islam.

Dalam bahasa ushul fiqh, praktik-praktik budaya itu dikategorikan menjadi 'urf shâlih dan 'urf fâsid. 'Urf shâlih adalah kebiasaan yang tidak bertentangan dengan dalil syar' $\hat{\imath}$ dan dapat diterima karena tidak menghalalkan yang haram dan tidak pula mengharamkan yang wajib. Sedangkan 'urf fâsid adalah kebiasaan pada tarap menghalalkan yang diharamkan Allah atau mengharamkan yang dihalalkan Allah sehingga tertolak. ${ }^{20}$

${ }^{20}$ Mengutip pendapat Abdul Karim Zaidan, Satria Effendi M. Zein mendefinisikan ' urf atau adat istiadat sebagai sesuatu yang tidak asing lagi bagi suatu masyarakat karena telah menjadi kebiasaan dan menyatu dengan kehidupan mereka baik berupa perbuatan maupun perkataan, atau dalam bahasa Arab sebagai berikut.

$$
\text { ما ألفه المجتمع واعتاده وسار عليه في حياته من قول أو فعل }
$$


Sistem budaya merupakan suatu blue print behavior yang memberikan pedoman tentang apa yang harus dilakukan dan apa yang dilarang. Nilai-nilai budaya merupakan pedoman dan pendorong bagi perilaku manusia dalam interaksi sosial. Pembuatan hukum pada hakikatnya merupakan penjabaran secara konkret nilainilai yang berkembang di tengah masyarakat atau penetapan pola perilaku manusia yang ajeg sebagai norma atau kaidah hukum guna menjadi pedoman atau patokan bagi perilaku atau sikap tindak yang dianggap pantas atau yang seharusnya. Sedangkan penegakan hukum pada hakikatnya adalah penyerasian antara nilai-nilai yang dianut oleh masyarakat mengenai apa yang baik dan apa yang buruk. $^{21}$

\section{Kehadiran Islam dan Budaya dalam Pembentukan Hukum}

Baik Islam maupun budaya telah memperlihatkan fungsinya sebagai sumber informasi karena kedekatannya dari dunia transendental atau kebenaran jati. Keduanya secara nyata telah hadir dan berpengaruh dalam membentuk pola perilaku bermasyarakat dan bernegara. Kehadiran dan pengaruh tersebut dapat diuraikan dalam beberapa peristiwa sejarah pembentukan hukum dan peraturan perundang-undangan sebagai berikut.

\section{Perumusan Dasar Negara}

Usaha untuk menjadikan Islam secara formal sebagai bagian dalam sistem kenegaraan Indonesia telah dimulai ketika bangsa ini merumuskan dasar negara di masa perjuangan kemerdekaan. Meskipun waktu itu belum ada partai politik, bukan berarti tidak ada lembaga politik. Semua wadah perjuangan kemerdekaan hakikatnya adalah lembaga politik, termasuk lembaga-lembaga bentukan Jepang, yakni Badan Penyelidik Usaha-usaha Kemerdekaan Indonesia (BPUPKI), Panitia Persiapan Kemerdekaan Indonesia (PPKI), dan Panitia Sembilan. Sebab, di dalam lembaga-lembaga itu terdapat persaingan yang bermuara pada kekuasaan untuk mengelola negara. BPUPKI sesuai dengan namanya membicarakan persiapan

Satria Effendi M. Zein, Ushul Figh (Jakarta: Kencana, 2005), 154-155. Baca pula Abdul Wahhab Khalaf, 'Ilm Ushûl al-Figh, (Kuwait: Dar al-Qalam, 1978 M/1398 H), 89-91.

21 Soerjono Soekanto, Faktor-Faktor yang Mempengaruhi Penegakan Hukum, Edisi Pertama, Cet. V, (Jakarta: PT RajaGrafindo Persada, 2004), 1-6. 
kemerdekaan Indonesia beserta perlengkapannya antara lain dasar negara. Badan ini beranggotakan 68 orang dengan komposisi 8 orang dari Jepang, 15 orang dari golongan Islam, dan selebihnya dari golongan nasional sekuler dan priyayi Jawa. Radjiman Wedyadiningrat sebagai ketua adalah seorang mistik Jawa. Oleh karena anggota-anggota dari Jepang tidak aktif, maka praktis hanya dua golongan yang berhadapan, yaitu Islam di satu pihak dan nasional sekuler bersama priyayi Jawa di pihak lain. ${ }^{22}$

Ketika membahas tentang dasar negara, kedua kubu tersebut berbeda pandangan. Golongan Islam menghendaki negara Islam, sedangkan golongan sekuler menghendaki negara nasional yang memisahkan urusan negara dan urusan Islam. Terjadi pro dan kontra yang kuat. Untuk itu dibentuk Panitia Sembilan yang diketuai Soekarno, dengan delapan anggotanya beragama Islam dan hanya A.A. Maramis yang beragama Kristen.

Demi kemerdekaan dan persatuan Indonesia, golongan Islam menarik kembali usul pembentukan negara Islam. Sebagai kompromi muncul Piagam Jakarta yang di dalamnya terdapat rumusan "Ketuhanan dengan kewajiban menjalankan syari'at Islam bagi pemeluk-pemeluknya." Piagam Jakarta ini direncanakan menjadi dasar negara Indonesia. Dalam perkembangannya rumusan dalam Piagam Jakarta itu diubah menjadi Ketuhanan Yang Maha Esa sebagaimana sila pertama Pancasila, dan kata mukaddimah diganti dengan pembukaan. Meski sempat protes ketika hasil Panitia Sembilan itu dibacakan dalam sidang PPKI, golongan Islam akhirnya menerima dengan alasan persatuan dan kesatuan. Dalam konteks ini, menurut Alamsyah, ${ }^{23}$ umat Islam telah berkorban dua kali, yaitu citacita mendirikan negara Islam di negara yang mayoritas penduduknya beragama Islam dan cita-cita memberlakukan hukum Islam pada

22 Sebutan dan pengelompokan itu mengandung makna yang berlebihan, seakan di luar golongan Islam adalah bukan Islam. Padahal kenyataannya tidak demikian. Supomo, anggota BPUPKI dari kelompok nasional sekuler, menyebut golongan Islam dengan ahli agama. Ini dimaksudkan bahwa golongan nasional sekuler pun sebagian beragama Islam, hanya saja mereka tidak ahli agama. Abdul Azis Thaba, Islam dan Negara dalam Politik Orde Baru, (Jakarta: Gema Insani Press, 1996), 153-155.

23 Alamsyah Ratu Prawiranegara, "Strategi Perjuangan Umat Islam di Bidang Hukum," dalam Amrullah Ahmad, dkk (eds.), Dimensi Hukum Islam dalam Sistem hukum Nasional Mengenang 65 Tahun Prof. Dr. Busthanul Arifin, SH (Jakarta: Gema Insani Press, 1996), 237-238. 
umat Islam dengan jaminan negara. Meski pada awalnya dibentuk dalam suasana yang serba darurat dan sementara, konsepsi negara Pancasila tersebut ${ }^{24}$ pada akhirnya telah diterima sebagai bentuk final.

\section{Pembedaan Warga Negara dan Hukum yang Berlaku}

Menjelang akhir masa penjajahan Belanda di Indonesia diberlakukan Staatsblad 1925, Nomor 447 tentang Indische Staatsregeling (IS) atau Peraturan Ketatanegaraan yang berlaku mulai 1 Januari 1926. Pasal 131 dan 163 IS membedakan masyarakat kolonial menjadi beberapa golongan penduduk dan memberlakukan sistem hukum yang berbeda bagi mereka. Dengan kata lain, pemerintah Belanda menerapkan sistem hukum yang plural, namun pada saat yang sama juga menciptakan sistem penghubung untuk menampung hubungan interaksi sosial antarmasyarakat yang pluralistis. Kebijakan itu dimaksudkan untuk mengakomodir agama dan budaya yang tumbuh dan berkembang dalam tiap-tiap masyarakat, sehingga dapat menciptakan ketertiban dalam masyarakat yang bersangkutan. ${ }^{25}$

Terlepas bahwa dalam sejarahnya kebijakan itu merugikan umat Islam, bagi Belanda hal itu menguntungkan. Dengan kebijakan itu kepentingan-kepentingan Belanda terlindungi dan pada saat yang sama tercapai ketertiban masyarakat. Penolakan umat Islam sesungguhnya tidak dialamatkan kepada kebijakan itu secara keseluruhan, melainkan akibat Pasal 134 IS yang menundukkan hukum Islam pada hukum adat. Dengan demikian, kebijakan itu sesungguhnya mengandung inkonsistensi di dalamnya sebab dimaksudkan untuk memperhatikan apa yang tumbuh dan berkembang dalam masyarakat, namun pada saat yang bersamaan telah mengabaikan Islam sebagai sebuah agama yang syarat dengan nilai-nilai khas.

24 Sejarah pembuatan UUD 1945, termasuk bagian pembukaan, sejak semula dimaksudkan bukan sebagai UUD yang permanen dapat dibaca dalam Mohammad Yamin, Naskah Persiapan Undang-Undang Dasar 1945, Jilid I (Jakarta: Penerbit Siguntang, 1959), 410 dan Moh. Mahfud MD, Demokrasi dan Konstitusi di Indonesia Studi tentang Interaksi Politik dan Kehidupan Ketatanegaraan, Cet. II, (Jakarta: Penerbit Rineka Cipta, 2003), 139-140.

${ }^{25}$ Liria Tjahaja, "Pluralisme Hukum dan Masalah Perkawinan Campuran," dalam E.K.M. Masinambow (ed.), Hukum dan Kemajemukan Budaya, Sumbangan Karangan untuk Menyambut Hari Ulang Tahun ke-70 Prof. Dr. T.O. Ihromi, (Jakarta: Yayasan Obor Indonesia, 2003), 116-119. 


\section{UU Perkawinan}

UU Nomor 1 Tahun 1974 tentang Perkawinan merupakan UU Perkawinan yang pertama kali dibentuk oleh bangsa Indonesia dan hingga kini masih berlaku. UUP menggantikan pengaturan tentang hal yang sama dalam KUHPer. Sebagai produk bangsa Indonesia sendiri UUP dianggap sangat memadai, sehingga membuatnya masih relevan sampai kini. Substansi yang baik dari UUP ini tidak dihasilkan melalui proses dan tahapan yang lurus dan datar saja. Kelahiran UUP ini penuh dengan intrik dan persaingan antar kelompok Islam dan kelompok non Islam di satu pihak, serta antara Departemen Agama yang dikuasai Nahdlatul Ulama (NU) dan Departemen Kehakiman yang dikuasai PNI.

Intrik bermula ketika Departemen Agama pada 1958 mengajukan paket RUU Perkawinan yang terdiri dari tiga RUU, yaitu RUU Perkawinan yang bersifat umum sebagai UU pokok, RUU Perkawinan untuk umat Islam, dan RUU Perkawinan untuk umat Kristen. Paket RUU Perkawinan itu gagal dibahas di Parlemen karena satu dari tiga belas fraksi menolak, yaitu Fraksi PNI. Pada saat yang sama Departemen Kehakiman juga mengajukan RUU Perkawinan yang bersifat umum dengan muatan yang sama dengan yang diajukan Departemen Agama. Kegaduhan dan kegagalan seperti ini berulang lagi sembilan tahun kemudian, ketika Departemen Agama (22 Mei 1967) dan Departemen Kehakiman (7 September 1968) masing-masing mengajukan RUU Perkawinan. ${ }^{26}$

Pasca Pemilu 1971 di mana Golkar tampil sebagai pemenang dan dengan dukungan ABRI memperoleh 336 kursi di DPR atau $73 \%$, pada 31 Juli 1973 diajukan lagi RUU Perkawinan oleh Presiden Soeharto. Alih-alih memuaskan keinginan umat Islam yang mendambakan kehadirannya, RUU Perkawinan itu substansinya mirip Ordonansi Perkawinan Tercatat 1937 yang pernah ditolak oleh umat Islam. Tak ayal RUU Perkawinan itu menuai protes dan kritik yang keras. Dengan RUU itu golongan Cina, Eropa, dan Kristen mendapatkan perlindungan hukum, sedangkan umat Islam yang mayoritas dipaksa keluar dari hukum Islam. Umat Islam

${ }^{26}$ Achmad Gunaryo, Pergumulan Politik dan Hukum Islam Reposisi Peradilan Agama dari Peradilan "Pupuk Bawang" Menuju Peradilan yang Sesungguhnya, (Yogyakarta: Kerjasama Pustaka Pelajar dan IAIN Walisongo Semarang, 2006), 127-128. 
menghendaki hukum Islam diperhatikan dalam penyusunan RUU Perkawinan. Bersamaan dengan penolakan RUU Perkawinan yang diajukan pemerintah, telah dihasilkan draf UU Perkawinan. Pada akhirnya draf yang disusun dalam forum lobi antara tokoh-tokoh ABRI dan para ulama itulah yang disetujui oleh DPR pada 22 Desember 1973 dan kemudian disahkan menjadi UU Perkawinan pada 2 Januari 1974. Keberhasilan itu dicapai berkat aliansi Presiden, ABRI, dan PPP, meskipun sempat ditolak oleh unsur-unsur Kristen dalam Fraksi Karya dan Fraksi Demokrasi. ${ }^{27}$

Keberhasilan UU Perkawinan tersebut merupakan test case tentang pluralitas hukum di Indonesia. Dalam kerangka unifikasi dan kodifikasi ternyata bisa dilakukan adopsi hukum Islam ke dalam hukum nasional tanpa mengorbankan kepentingan agama-agama lain. Keberhasilan itu pada saat yang bersamaan merupakan pembalikan konsepsional dari RUU Perkawinan yang diajukan.

\section{UU Peradilan Agama}

UU Nomor 7 Tahun 1989 tentang Peradilan Agama (UUPA) merupakan lanjutan cerita sukses umat Islam setelah UU Perkawinan. Berbeda dengan proses kelahiran UU Perkawinan yang berliku dan penuh intrik, kelahiran UUPA sangat mudah dan lancar. RUU PA diajukan pada 3 Desember 1988 dan telah disahkan menjadi UU pada 29 Desember 1989. Dengan demikian, dalam rentang waktu satu tahun pembahasan RUU PA telah selesai dilakukan. Arti penting UU ini adalah penguatan eksistensi Peradilan Agama sebagai salah satu pelaku kekuasaan kehakiman dengan kewenangannya yaitu memeriksa, memutus, dan menyelesaikan perkara-perkara antarorang beragama Islam di bidang perkawinan, kewarisan, wasiat, hibah, wakaf, dan shadaqah menurut hukum Islam. Arti penting lain dari UU ini adalah pengaturan PA secara utuh dalam kerangka sistem dan tata hukum nasional, setelah sebelumnya diatur secara berserakan dalam berbagai peraturan. ${ }^{28}$

\footnotetext{
27 Ibid., 131-153.

28 "Sambutan Pemerintah atas Persetujuan Dewan Perwakilan Rakyat terhadap Rancangan Undang-Undang tentang Peradilan Agama" tanggal 14 Desember 1989 dalam Undang-Undang Republik Indonesia Nomor 7 Tahun 1989 tentang Peradilan Agama Dilengkapi Kompilasi hukum Islam di Indonesia, (Surabaya: Pustaka Tinta Mas, 1996), ixxiii.
} 
Mulusnya pembahasan UUPA ini terjadi karena telah terjadinya perubahan politik di kalangan umat Islam seiring dengan keberhasilan pemerintah melemahkan politik dan kekuatan Islam. Diberlakukannya azas tunggal Pancasila pada 1985 mendapatkan respon positif dari kalangan Islam. Nahdlatul Ulama (NU), misalnya, sebagai unsur terbesar pendukung politik Islam memutuskan untuk kembali sebagai organisasi sosial keagamaan (khiththah) lewat Muktamar di Situbondo pada 1984. Sebagai konsekwensinya, NU menyatakan keluar dari PPP dan membebaskan warganya dalam berpolitik. Sejak itu warga NU dan tidak sedikit tokoh-tokohnya yang bergabung atau mendukung Golkar yang dahulu dianggap haram. ${ }^{29}$ Dengan demikian, UUPA itu merupakan responsi dan akomodasi dari pemerintah untuk umat Islam. Sebab, dengan menerima Pancasila sebagai asas tunggal dan memberikan dukungan kepada Golkar, umat Islam tidak lagi menjadi ancaman bagi pemerintah.

\section{Peraturan Perundang-Undangan di Bidang Ekonomi Islam}

Hingga beberapa dekade setelah kemerdekaan, perbankan konvensional yang menjadikan bunga sebagai basis operasionalnya menjadi satu-satunya sistem perbankan di Indonesia. Praktik perbankan yang bertumpu pada sistem bunga tersebut dirasakan bertentangan dengan keyakinan keagamaan umat Islam di Indonesia yang notabene mayoritas.

Menurut hukum Islam, yang merupakan salah satu pilar terpenting dari seluruh sistem dan bangunan Islam itu sendiri, sistem bunga hampir identik dengan riba yang keharamannya tidak diragukan lagi. 30

\footnotetext{
${ }^{29}$ Endang Turmudi, "Islam dan Politik," dalam Muhammad Hisyam, Krisis Masa Kini dan Orde Baru, (Jakarta: Yayasan Obor Indonesia, 2003), 376-377.

30 Keharaman riba memang bersifat pasti karena telah dinyatakan secara eksplisit baik dalam al-Qur'an maupun Sunnah. Namun, apakah bunga bank itu adalah riba, di kalangan ulama ada perbedaan pendapat. Itulah sebabnya status hukum bunga bank masih diperselisihkan di kalangan ulama. Ada yang berpendapat haram secara mutlak, karena identik dengan riba. Ada yang berpendapat haram dengan batasan, yaitu apabila untuk keperluan konsumtif dan bukan dilakukan oleh bank pemerintah. Ada pula yang memperbolehkan, baik karena alasan bukan termasuk riba yang diharamkan, atau karena alasan darurat. Ahmad Azhar Basyir, Hukum Islam tentang Riba, Utang-Piutang, Gadai, cetakan kedua (Bandung: PT. Alma'arif, 1983), 28-32; dan Ahmad Azhar Basyir, Refleksi atas Persoalan Keislaman Seputar Filsafat,
} 
Hal demikian telah menjadi keyakinan sebagian masyarakat muslim, sehingga kebutuhan mereka akan jasa-jasa perbankan tidak dapat dilayani oleh bank-bank konvensional/non syariah. Karena itu, keberadaan perbankan yang sesuai dengan ajaran Islam bagi umat Islam merupakan keniscayaan. ${ }^{31}$ Hanya saja karena berbagai alasan, baik politis maupun ekonomis, cita-cita dan harapan umat Islam Indonesia akan lahirnya perbankan Islam baru terwujud pada awal dekade 1990-an.

Kelahiran bank syariah ${ }^{32}$ di Indonesia ditandai dan bersamaan dengan disahkannya UU Nomor 7 Tahun 1992 tentang Perbankan (UUP 1992). Di negara penganut tradisi civil law seperti Indonesia dan kenyataan bahwa perbankan merupakan bidang yang banyak mendapatkan pengaturan (most heavily regulated), tanpa adanya produk perundang-undangan yang mengaturnya tidak mungkin perbankan syariah bisa beroperasi. Pasca krisis moneter tahun 1997 UU Perbankan diubah dengan UU Nomor 10 Tahun 1998 tentang Perubahan Atas UU Nomor 7 Tahun 1992 tentang Perbankan (UUP 1998). Selanjutnya perbankan syariah diatur secara khusus dalam UU Nomor 21 Tahun 2008 tentang Perbankan Syariah (UUPbS). Dengan

Hukum, Politik dan Ekonomi, (Bandung: Mizan, 1993), 183. Dalam perspektif yang lain Sutan Remy membuat kategorisasi pendapat ulama tentang bunga bank menjadi tiga. Pendapat yang mengharamkan bunga bank secara mutlak oleh karena merupakan riba nasî'ah dikemukakan oleh kelompok konservatif. Sedang pendapat yang memperbolehkan bunga bank secara mutlak oleh karena bukan termasuk riba yang diharamkan dikemukakan oleh kelompok pragmatis. Sementara itu kelompok sosioekonomis yang mempunyai latar belakang pendidikan ekonomi melarang bunga bank dengan alasan cenderung menjadi ajang pengumpulan kekayaan di tangan segelintir orang saja. Lebih lanjut baca Sutan Remy Sjahdeini, Perbankan Islam Dan Kedudukannya Dalam Tata Hukum Perbankan Indonesia, Cet. III, (Jakarta: PT. Pustaka Utama Grafiti, 2007), 10-118.

31 Syahril Sabirin dalam kata sambutannya selaku Gubernur Bank Indonesia dalam Muhammad Syafi'i Antonio (1), Bank Syariah Wacana Ulama E Cendekiawan, (Jakarta: BI dan Tazkia Institute, 1999), ix-x.

32 Berbeda dengan Malaysia yang memakai istilah bank Islam, di Indonesia dipakai istilah bank syariah. Agaknya nama Islam di Indonesia masih menakutkan bagi beberapa kalangan yang mengalami Islamic phobia. Karena itu dipakailah istilah syariah yang masih asing bagi mereka, meski sesungguhnya mengandung arti yang tidak berbeda. Bahkan pada awal kemunculannya yang dipakai adalah istilah bank berdasarkan prinsip bagi hasil. Setelah hampir satu dekade istilah itu diubah menjadi bank yang menjalankan kegiatan berdasarkan prinsip syariah dan selanjutnya baru dipakai istilah bank syariah. 
demikian, perbankan syariah telah diakui sejajar dengan perbankan konvensional dalam suatu dual banking system. Selain beberapa UU tersebut, perbankan syariah banyak diatur dalam peraturanperaturan di bawah UU antara lain secara berurutan Peraturan Pemerintah, SK Direksi Bank Indonesia, Peraturan Bank Indonesia, dan belakangan Peraturan Otoritas Jasa Keuangan (OJK).

Beroperasinya perbankan syariah selanjutnya diikuti oleh subsubsistem ekonomi Islam yang lain, yaitu asuransi syariah (takâful), pasar modal syariah, surat berharga syariah, dan lembaga-lembaga pembiayaan syariah. Seperti halnya perbankan syariah, pengaturan asuransi syariah semula bersifat sambil lalu dalam UU Nomor 2 Tahun 1992 tentang Usaha Perasuransian dan peraturan-peraturan pelaksanaannya yang semula diperuntukkan bagi asuransi konvensional. Berikutnya pengaturan asuransi syariah semakin kuat dan posisinya seimbang dengan pengaturan asuransi konvensional dengan disahkannya UU Nomor 41 tahun 2014 tentang Perasuransian.

Pasar modal syariah secara umum diatur dalam UU Nomor 8 Tahun 1995 tentang Pasar Modal dan secara khusus dalam Keputusan Kepala Badan Pengawas Pasar Modal (BAPEPAM). Dengan dibentuknya OJK sesuai UU Nomor 21 Tahun 2011 tentang OJK, kewenangan pengaturan pasar modal syariah berpindah dari BAPEPAM ke OJK. Surat berharga syariah semula diatur dalam beberapa Peraturan Bank Indonesia, namun kemudian diatur dalam Peraturan OJK. Khusus surat berharga syariah yang diterbitkan negara diatur dalam UU Nomor 19 Tahun 2008 tentang Surat Berharga Syariah Negara. Sementara itu lembaga keuangan mikro syariah diatur dalam UU Nomor 1 Tahun 2013 tentang Lembaga Keuangan Mikro dan ditindak lanjuti dengan beberapa Peraturan OJK.

Lahirnya peraturan-peraturan perundang-undangan tentang ekonomi Islam itu terjadi ketika umat Islam telah diakomodasi oleh pemerintah dan terus berlangsung ketika artikulasi politik umat Islam mengalami penguatan pasca reformasi. Oleh karena itu proses kelahirannya relatif mudah atau bahkan sangat mudah. Kelahiran peraturan-peraturan perundangan itu hampir tanpa perlawanan (: keberatan) dari kekuatan politik yang ada, baik dari non muslim atau umat Islam sendiri. 
Ja'far Baehaqi

\section{UU Pemerintahan Daerah (Pemda)}

Terdapat perbedaan konsepsi pemerintahan daerah sebelum dan sesudah perubahan UUD NRI 1945. Sebelum perubahan UUD, terutama masa Orde Baru pemerintahan daerah diatur dalam UU Nomor 5 Tahun 1974 tentang Pokok-pokok Pemerintahan Daerah. UU ini berisi pokok-pokok penyelenggaraan pemerintahan yang menjadi tugas pemerintah pusat di daerah. Memang dalam UU tersebut dielaborasi daerah-daerah otonom dan penyelenggaraan pemerintahan daerah berasaskan desentralisasi, dekonsentrasi, dan tugas pembantuan, namun pemberian otonomi dikaitkan dengan kondisi politik, ekonomi, sosial-budaya serta pertahanan dan keamanan nasional. Manakala sistem politik bersifat represif dan tidak demokratis, dan segala sesuatunya serba tersentralisasi, maka otonomi daerah adalah nonsen. Tak ayal, daerah tidak dapat berkembang secara optimal. Segala kebijakan tentang daerah diputuskan oleh pusat. Daerah tidak memiliki keleluasaan untuk mengembangkan potensi yang dimilikinya. ${ }^{33}$

Dengan perubahan UUD NRI 1945 daerah mempunyai kewenangan mengatur dan mengurus sendiri urusan pemerintahan menurut asas otonomi dan tugas pembantuan. Otonomi tersebut diberikan seluas-luasnya dengan memperhatikan kekhususan dan keragaman daerah. Kecuali itu, kesatuan masyarakat hukum adat beserta hak-hak tradisionalnya juga diakui dan dihormati. Hal itu berarti budaya telah diakomodir dalam sistem hukum nasional. Pemerintahan daerah pasca perubahan UUD NRI 1945 diatur dalam UU Nomor 22 Tahun 1999 tentang Pemerintahan Daerah. Selanjutnya UU Pemda ini dikoreksi dan diganti dengan UU Nomor 32 Tahun 2004 tentang Pemerintahan Daerah. Setelah sepuluh tahun UU Pemda ini diganti dengan UU Nomor 23 Tahun 2014 berikut perubahannya. ${ }^{34}$

Otonomi daerah pasca amandemen UUD NRI 1945 telah dimaknai secara beragam oleh daerah, baik secara positif maupun negatif. Di antara yang positif adalah elaborasi kekhasan daerah

\footnotetext{
33 Ni'matul Huda, Hukum Tata Negara Indonesia, (Jakarta: PT RajaGrafindo Persada, 2006), 332-334.

34 Yaitu melalui UU Nomor 2 Tahun 2015 tentang Perubahan Pertama UU Nomor 23 Tahun 2014 tentang Pemerintahan Daerah dan UU Nomor 9 Tahun 2015 tentang Perubahan Kedua UU Nomor 23 Tahun 2014 tentang Pemerintahan Daerah.
} 
dalam produk-produk peraturan daerah. Di sini terdapat fenomena lahirnya perda-perda syariat, yaitu perda-perda yang berisi positivisasi ajaran Islam di daerah yang mayoritas warganya beragama Islam. Di tempat lain juga lahir perda-perda yang bernuansa ajaran agama non-Islam di daerah yang mayoritas warganya non-muslim, misalnya Perda Injil di Manokwari Papua.

Pengaturan Pemerintahan Daerah yang dinamis dan responsif tersebut bisa terjadi karena demokrasi telah berjalan dengan baik pasca reformasi. Pada sisi lain faktor penyebabnya adalah tiadanya partai politik yang mampu mencapai mayoritas tunggal seperti Golkar pada masa Orde Baru. Semua partai politik berkepentingan terhadap pengaturan pemerintahan daerah karena mereka mempunyai basis massa di daerah-daerah yang kepala daerahnya adalah kadernya.

\section{UU Mahkamah Konstitusi}

Salah satu perkembangan penting dalam sistem ketatanegaraan Indonesia pasca kekuasaan Orde Baru adalah kehadiran Mahkamah Konstitusi. Mahkamah Konstitusi lahir berkat Amandemen ketiga (2001) dan keempat (2002) UUD 1945. Mahkamah Konstitusi resmi berdiri pada 13 Agustus 2003 bersamaan dengan disahkannya UU Nomor 24 Tahun 2003 tentang Mahkamah Konstitusi (UUMK) yang kemudian diubah dengan UU Nomor 8 Tahun 2011.

Menurut Pasal 24C ayat (1) UUD 1945 yang kemudian dimuat ulang dalam Pasal 10 ayat (1) UUMK, MK berwenang mengadili pada tingkat pertama dan terakhir yang putusannya bersifat final untuk (1) menguji undang-undang terhadap Undang-Undang Dasar; (2) memutus sengketa kewenangan lembaga negara yang kewenangannya diberikan oleh Undang-Undang Dasar; (3) memutus pembubaran partai politik; dan (4) memutus perselisihan tentang hasil pemilihan umum. Kecuali itu, menurut Pasal 24C ayat (2) yang dimuat ulang dalam Pasal 10 ayat (2) UU MK terkait dengan pemakzulan (impeachment), Mahkamah Konstitusi wajib memberikan putusan atas pendapat Dewan Perwakilan Rakyat bahwa Presiden dan/atau Wakil Presiden diduga telah melakukan pelanggaran hukum berupa pengkhianatan terhadap negara, korupsi, penyuapan, tindak pidana berat lainnya, atau perbuatan tercela, dan/atau tidak 
lagi memenuhi syarat sebagai Presiden dan/atau Wakil Presiden sebagaimana dimaksud dalam Undang-Undang Dasar 1945.

Kelahiran Mahkamah Konstitusi (MK) terkait dengan gagasan mengenai pelembagaan/institusionalisasi sebuah lembaga peradilan tatanegara, yang keberadaannya tidak lepas dari upaya serius untuk memberikan perlindungan terhadap hak-hak konstitusional warga negara, yang seringkali terancam oleh kesewenang-wenangan pemerintah berkuasa. Upaya ini selanjutnya melahirkan konsepsi "constitutional review" atau pengujian konstitusional. Jika ditarik ke masa lebih awal, konsepsi ini lahir sebagai buah perkembangan pemikiran dari gagasan tentang negara hukum, prinsip pemisahan kekuasaan, dan upaya perlindungan serta pemajuan hak asasi manusia (HAM). Dengan demikian, konsep "constitutional review" merupakan kolaborasi tiga ide dasar tersebut, sebagai jawaban atas kebutuhan adanya suatu pemerintahan modern yang demokratis. ${ }^{35}$

Bersamaan dengan dielaborasinya Mahkamah Konstitusi, konsepsi HAM dimunculkan dalam UUD NRI 1945 yang antara lain meliputi hak kebebasan memeluk agama dan beribadat menurut agamanya (Pasal 28E ayat [1]), dan penghormatan terhadap identitas budaya dan hak masyarakat tradisional selaras dengan perkembangan zaman dan peradaban (Pasal 28I ayat [3]). Sejalan dengan itu juga disahkan UU Nomor 5 Tahun 2004 tentang Perubahan UU Nomor 14 Tahun 1985 tentang Mahkamah Agung. Perubahan yang dielaborasi UU tersebut adalah Pasal 31 terkait dengan uji materiil peraturan perundang-undangan di bawah UU terhadap UU. Substansi perubahannya adalah bahwa pemeriksaan uji materiil tersebut bisa dilakukan dalam pemeriksaan di tingkat kasasi maupun berdasarkan permohonan langsung kepada MA.

Dengan meletakkan Islam dan budaya menjadi bagian dari HAM yang harus dilindungi, maka dengan konstruksi demikian dapat dinyatakan bahwa tiap produk peraturan perundangundangan yang mengabaikan atau bertentangan dengan Islam dan budaya dinyatakan tidak konstitusional dan karenanya tidak mempunyai kekuatan mengikat. Dengan ungkapan yang lain, lembaga atau pejabat pembentuk hukum tidak boleh berlaku semena-

35 Jimly Asshiddieqie, Model-Model Pengujian Konstitusional di Berbagai Negara, (Jakarta: Konstitusi Press, 2005), 8-9. 
mena membuat peraturan yang bertentangan dengan Islam dan budaya.

\section{Beberapa UU tentang Pelaksanaan Ajaran Islam}

Seperti telah dikemukakan di atas, ajaran Islam dibedakan antara yang berdimensi ibadah ritual dan yang berdimensi sosial. Keduanya telah hadir dalam pembentukan hukum di Indonesia. UU Nomor 23 Tahun 2011 tentang Pengelolaan Zakat, ${ }^{36}$ UU Nomor 41 Tahun 2004 tentang Wakaf, UU Nomor 13 Tahun 2008 tentang Penyelenggaraan Ibadah Haji ${ }^{37}$ berikut perubahannya yaitu UU Nomor 34 Tahun 2009 tentang Penetapan Peraturan Pemerintah Pengganti Undang-Undang Nomor 2 Tahun 2009 tentang Perubahan UU Nomor 13 Tahun 2008 tentang Penyelenggaraan Ibadah Haji, dan UU Nomor 1/PnP Tahun 1965 tentang Pencegahan Penyalahgunaan dan/atau Penodaan Agama merupakan peraturan-peraturan yang dimaksudkan untuk melindungi agama, menunjang dan mempermudah pelaksanaan ajaran agama, dan mendayagunakan serta memberikan nilai tambah dalam pelaksanaan ajaran agama.

Keterlibatan negara dalam pelaksanaan ajaran-ajaran agama tersebut tidak saja bagian dari pelayanan dan perlindungan terhadap warga negara, melainkan juga karena faktor kepentingan negara. Ialah kepentingan yang terkait dengan substansi ajaran agama yang berhimpitan dengan tugas dan tanggung jawab negara. Dengan demikian, dari perspektif apa pun negara diuntungkan dan karenanya merasa perlu mengaturnya dalam peraturan perundangundangan sebagai instrumen kebijakan.

\section{Penutup}

Islam dan budaya merupakan dua entitas dengan kesamaan dan sekaligus perbedaan. Dalam konteks pembentukan hukum, keduanya berada dalam ranah yang sama, yaitu pemberi informasi yang cenderung mempedomani. Artinya pembentukan hukum mesti memperhatikan dan mempertimbangkan eksistensi keduanya, baik secara bersamaan maupun sendiri-sendiri, sehingga gap antara hukum yang dihasilkan dengan keduanya dapat diminimalisir.

\footnotetext{
36 UU ini menggantikan UU Nomor 38 Tahun 1999 tentang Pengelolaan Zakat.

37 UU ini menggantikan UU Nomor 17 Tahun 1999 tentang Penyelenggaraan Ibadah Haji.
} 
Dalam banyak kasus, Islam dan budaya menjadi penopang eksistensi hukum nasional. Di sini antara Islam dan budaya bisa terjadi saling sinergi dan bisa pula sebaliknya saling berkompetisi dan saling menafikan satu sama lain. Kehadiran dan pengaruh Islam dalam pembentukan hukum mempersyaratkan setidaknya tiga hal, yaitu akomodasi negara dan/atau penguatan peran politik umat Islam, internalisasi ajaran Islam, dan pemilihan strategi yang tepat. Di luar itu diperlukan adanya sistem politik yang demokratis, perkembangan pemikiran dan gagasan tentang negara hukum, prinsip pemisahan kekuasaan, dan upaya perlindungan serta pemajuan hak asasi manusia (HAM).

\section{Daftar Pustaka}

Ahmad, Amrullah, dkk (eds.), Dimensi Hukum Islam dalam Sistem hukum Nasional Mengenang 65 Tahun Prof. Dr. Busthanul Arifin, SH, Jakarta: Gema Insani Press, 1996.

Antonio, Muhammad Syafi'i, Bank Syariah Wacana Ulama $\mathcal{E}$ Cendekiawan, Jakarta: BI dan Tazkia Institute, 1999.

Asshiddieqie, Jimly, Model-Model Pengujian Konstitusional di Berbagai Negara, Jakarta: Konstitusi Press, 2005.

Baehaqi, Ja'far, "Dialektika Hukum Islam dan Hukum Nasional dalam formulasi Hukum Perbankan Syariah di Indonesia", Disertasi tidak diterbitkan, Program Doktor Ilmu Hukum Fakultas Hukum Universitas Diponegoro Semarang 2013.

Basyir, Ahmad Azhar, Hukum Islam tentang Riba, Utang-Piutang, Gadai, cetakan kedua, Bandung: PT. Alma'arif, 1983.

------, Refleksi atas Persoalan Keislaman Seputar Filsafat, Hukum, Politik dan Ekonomi, Bandung: Mizan, 1993.

Bisri, Cik Hasan, Hukum Islam di Indonesia, Pengembangan dan Pembentukan, Bandung: PT. Rosda Karya, 1991.

Daeng, Hans J., Manusia, Kebudayaan dan Lingkungan Tinjauan Antropologis, Yogyakarta: Pustaka Pelajar, 2000.

Friedman, Lawrence M., The Legal System, A Social Science Perspective, New York: Russel Sage Foundation, 1975.

Gunaryo, Achmad, Pergumulan Politik dan Hukum Islam Reposisi Peradilan Agama dari Peradilan "Pupuk Bawang" Menuju 
Peradilan yang Sesungguhnya, Yogyakarta: Kerjasama Pustaka Pelajar dan IAIN Walisongo Semarang, 2006.

Himawan, Anang Haris (peny.), Epistemologi Syara': Mencari Format Baru Figh Indonesia, Yogyakarta: Walisongo Press bekerjasama dengan Pustaka Pelajar, 2000.

Hisyam, Muhammad, Krisis Masa Kini dan Orde Baru, Jakarta: Yayasan Obor Indonesia, 2003.

Huda, Ni'matul, Hukum Tata Negara Indonesia, Jakarta: PT RajaGrafindo Persada, 2006..

Khallaf, 'Abd al-Wahhab, 'Ilmu Ushul al-Figh, Kuwait: Dar al-Qalam, $1978 \mathrm{M} / 1398 \mathrm{H}$.

King, Nat J. Colletta dan Kayam, Umar, Kebuadayaan dan Pembangunan Sebuah Pendekatan terhadap Antroologi Terapan di Indonesia, Jakarta: Yayasan Obor Indonesia, 1987.

Koentjaraningrat, Pengantar Antropologi, Jakarta: Rineka Cipta, 1991.

Mahfud MD, Moh., Demokrasi dan Konstitusi di Indonesia Studi tentang Interaksi Politik dan Kehidupan Ketatanegaraan, cetakan kedua, Jakarta: Penerbit Rineka Cipta, 2003.

Pustaka LP3ES, 2001.

Masinambow, E.K.M. (ed.), Hukum dan Kemajemukan Budaya, Sumbangan Karangan untuk Menyambut Hari Ulang Tahun ke-70 Prof. Dr. T.O. Ihromi, Jakarta: Yayasan Obor Indonesia, 2003.

Meinarno, Eko A., dkk., Manusia dalam Kebudayaan dan Masyarakat Pandangan Antropologi dan Sosiologi, edisi 2, Jakarta: Salemba Humanika, 2011.

Rahardjo, Satjipto, Ilmu Hukum, cetakan kelima, Bandung: PT. Citra Aditya Bakti, 2000.

--------, Membangun dan Merombak Hukum Indonesia Sebuah Pendekatan Lintas Disiplin, Yogyakarta: Genta Publishing, 2009.

Rahman, Jamal D. (et al.), Wacana Baru Fiqih Sosial, 70 Tahun Prof. K.H. Ali Yafie, cetakan 1, Bandung: Mizan, 1997.

Rosyidi, Suherman, Pengantar Teori Ekonomi Pendekatan kepada Teori Ekonomi Mikro dan Makro, edisi baru, Jakarta: PT RajaGrafindo Persada, 2004.

"Sambutan Pemerintah atas Persetujuan Dewan Perwakilan Rakyat terhadap Rancangan Undang-Undang tentang Peradilan Agama" tanggal 14 Desember 1989 dalam Undang-Undang 
Republik Indonesia Nomor 7 Tahun 1989 tentang Peradilan Agama Dilengkapi Kompilasi hukum Islam di Indonesia, Surabaya: Pustaka Tinta Mas, 1996.

Sjahdeini, Sutan Remy, Perbankan Islam Dan Kedudukannya Dalam Tata Hukum Perbankan Indonesia, cetakan 3, Jakarta: PT. Pustaka Utama Grafiti, 2007.

Soekanto, Soerjono, Faktor-Faktor yang Mempengaruhi Penegakan Hukum, edisi pertama, cetakan kelima, Jakarta: PT RajaGrafindo Persada, 2004.

Thaba, Abdul Azis, Islam dan Negara dalam Politik Orde Baru, Jakarta: Gema Insani Press, 1996.

Yafie, Ali, Menggagas Fiqih Sosial, cetakan 2, Bandung: Mizan, 1994.

Yamin, Mohammad, Naskah Persiapan Undang-Undang Dasar 1945, Jilid I, Jakarta: Penerbit Siguntang, 1959.

Zein, Satria Effendi M., Ushul Fiqh, Jakarta: Kencana, 2005.

"India Akan Kalahkan Indonesia Soal Pemeluk Islam" dalam https://m.tempo.co/read/new diakses tanggal 2 Juli 2016.

"Penduduk Menurut Wilayah dan Agama yang Dianut" dalam http://sp2010.bps.go.id/index.php/si diakses tanggal 2 Juli 2016. 